\title{
'We Were Controlled, We Were Not Allowed to Express Our Sexuality, Our Intimacy Was Suppressed': Sexual Violence Experienced by Boys
}

\author{
Omer Aijazi, Evelyn Amony and Erin Baines ${ }^{1}$
}

Why are academic and policy discourses on child soldiers relatively silent on the sexual violence of boys in armed groups? In August of 2006, Erin Baines - one of the authors - accompanied journalists from the Canadian Broadcasting Corporation (CBC) to an internally displaced person's camp in Anaka, northern Uganda, to document the consequences of the ongoing war upon children. One of the interviewees was Fred, a young boy who had been abducted by the Lord's Resistance Army (LRA) at the age of 13 and coerced into their ranks. At the time of the interview, Fred had just escaped the LRA to reunite with his family in Anaka. Fred shared his unease: he was continuously disturbed by nightmares and often took to sleepwalking. Even though he was only in the LRA for a few months, Fred was forced to kill and rape civilians. He recalled one incident in which he was forced to rape an elderly woman. How should we approach Fred's experience? Can this event be considered a dual form of sexual violence inflicted on Fred and the elderly woman? This was the first time Erin knowingly spoke to a male survivor of wartime rape. Fred challenged her conceptions of not only who should be considered a victim of sexual violence in wartime, but also the forms sexual violence may take.

Fred reminds us of the insufficient attention to the sexual harms men and boys endure in wartime. Literature and policy on sexual violence and 'child soldiers' pays less attention to the ways boys are victims. ${ }^{2}$ Instead, scholarly and policy research has more often centred on girl's and women's experiences of sexual violence within an armed group, such as, for example, concubinage, forced marriage, pregnancy and sterilization or abortion, as well as rape and sexual mutilation. ${ }^{3}$ A reason often cited for this exclusion is the social taboos regarding sexual violence against boys and men, where norms regarding gender and sexuality intersect to 'doubly silence' and render the experiences of these victims invisible. Another is the inadvertent (at times purposeful) exclusion of boys and men from the work of legal feminist scholars who are sometimes singularly focused on the inclusion of women and girls in the global agenda on sexual violence and in the development of international legal cases. ${ }^{4}$

Fred also reminds of the insufficient language that exists on sexual violence. While an increasing number of studies of sexual violence in wartime urge closer attention to the ways state armed forces and non-state armed groups target men and boys, gender and age based normative assumptions persist. ${ }^{5} \mathrm{We}$ use the terms 'boys' and 'men' to refer to an age-based spectrum in relation to experiences of wartime sexual violence. However, we are cognizant that these categorizations are vague and often rooted within Western conceptions of adulthood. ${ }^{6}$ Some authors consider the causes of sexual violence against women and men, often drawing on the lens of masculinity to explain both its occurrence and underreporting. ${ }^{7}$ Other studies document forms of sexual violence experienced - from rape, to genital mutilation, enforced sterilization, enforced nudity and enforced masturbation - and explore why such cases are

\footnotetext{
${ }^{1}$ This research was supported by a Standard Research Grant from the Social Sciences and Research Council (SSHRC) of Canada, and the Conjugal Slavery in War (CSiW) SSHRC Partnership.

${ }^{2}$ We use the term 'child soldier' but are aware of the racialized infantilization such a label may suggest. See, Macmillan 2009.

${ }^{3}$ Coulter 2015; Baines 2016.

${ }^{4}$ See the following debate between Chris Dolan and Jeanne Ward: Dolan 2014a; Ward 2016; Dolan 2016.

${ }^{5}$ See, e.g. Solangon and Patel 2012.

${ }^{6}$ To this effect, we remain dissatisfied with the language of 'boys' and 'men' which lends to dualistic and binary thinking despite our intentions otherwise. This is a challenge: how to work against categories and categorical thinking in the absence of adequate language?

${ }^{7}$ Vojdik 2014; Rosemary and Shepherd 2013. ${ }^{7}$

Sivakumaran 2007.
} 
underreported to service providers and judicial institutions. ${ }^{7}$ Others consider how sexual violence against men and boys has failed to be prosecuted in international law, ${ }^{8}$ or trace its recent evolution. ${ }^{9}$ Still others consider the immediate and long term social and health impacts of such violations for the victim and within communities where the violence took place. ${ }^{10}$ Context specific case studies have been increasingly documented to allow the consideration of actual lived experience within the otherwise sterile and generalized remits of academia and policy. ${ }^{11}$ Across studies, focus and location, gendered and age-based assumptions of victimhood and guilt persist, even if the experiences of boys and men are now the focus. In legal narratives of sexual harm, men are most often assumed to be perpetrators, children are considered innocent and power is understood to exist as an absolute. Again, we ask, how should we approach Fred's violation(s)?

Drawing from the experiences of boys forcibly conscripted into the LRA, we seek to move beyond the gendered, limiting language of sexual slavery, concubines, forced pregnancy and rape in relation to child soldiers. We start with the premise that in settings of coercion - such as that of the LRA where forced conscription was endemic - most intimate and sexual relations were in themselves violent impositions. This allows us to reconsider our understanding of culpability and opens an entry point for examining experiences of sexual violence without falling into the conceptual trap of girls and women as victims and boys and men as perpetrators found in second wave feminist legal studies. ${ }^{12}$ In our opinion, this conceptual trap has been an obstacle for substantively understanding the experiences of sexual violence amongst boys and men in armed groups. We note the problematics of localising the harms of sexual violence using the labels of 'child' and 'adult' knowing that there are no universal or fixed distinctions between children and adults - a transition less marked by age but by contextualized understandings of responsibility and kinship. We are also mindful of the inconsistent approaches to 'child soldiers' within the liberal imagination, which is heavily marked by a skewed racial representation of vulnerability and ethics. ${ }^{13}$ We suggest a relational approach to sexual violence in settings of coercion and where one's sexuality is controlled, and intimacy is supressed. A relational approach enables us to move beyond an understanding of patriarchal power as totalizing by attending to the context specific constructions of age, race, ability and sexuality as they intersect. This is crucial, we suggest, to develop analytical assemblages beyond ageist and gendered understandings of sexual violence.

\section{Methods}

After her encounter with Fred, Erin continued to work in northern Uganda on a multi-year research project with female survivors of forced abduction and marriage in the LRA. Despite Fred's disruption of common feminist assumptions about sexual violence and victimhood, Erin did not think of including in her study the lived and felt experiences of men who were abducted as children. It was only when the participants of her study began to reference how both girls and boys were sometimes raped inside the LRA that Erin further considered how her own research design may be contributing to the erasure of boy's experiences in the armed group. ${ }^{13}$ In 2014, Erin and another scholar, Evelyn Amony, conducted a series of preliminary interviews and focus group discussions with men who had been forced to soldier at a young age in the LRA. The goal for these interviews was to generate discussion on the occurrence of sexual violence inside the group.

Exploratory in design, the study comprises unstructured focus group discussions (FGD) and openended individual interviews conducted in 2014 and 2015. This research took place in Gulu town, Acholi-bur, Pader Town Council and Ngoto in northern Uganda. Most participants were men who were abducted by the LRA and who fought for 1 to 17 years following brutal processes of socialization and

\footnotetext{
${ }^{8}$ Lewis 2009; Touquet and Gorris 2016. See also Ooosterveld in this volume who observes that sexual violence committed against boys was not examined by the Special Court for Sierra Leone, despite indications that such violations likely occurred.

${ }^{9}$ Oosterveld 2014.

${ }^{10}$ Christian et al. 2011; Chynoweth et al. 2017.

11 Touquet 2018; Clark 2017; Chynoweth 2017.

12 Buss 2009; Mibenge 2013. ${ }^{13}$ Moynagh 2014.

${ }^{13}$ On the multiple and intersecting institutions that silence male survivors - including academic - see Schulz 2018.
} 
training. Most participants were abducted between the ages of 13 and 20 and hence came of age in the armed group. Participants fought and lived in South Sudan, northern Uganda, the Democratic Republic of Congo and Central African Republic. All but one - a Brigade commander - held junior to mid-level ranks in the LRA, ranging from private, second or first lieutenant, and captain. The Women's Advocacy Network, a grassroots organization with 900 members of war affected men and women throughout northern Uganda, assisted in the identification of participants for this study.

The fieldwork was completed in collaboration with a team of Ugandan research assistants. In the focus group discussions, participants were asked to speak of their experiences of sexual violence within the LRA. These discussions were then supplanted with individual interviews. Thirty-three demobilized male soldiers were interviewed or participated in focus group discussions. All interviews and discussions were conducted in Luo-Acholi, the local vernacular. We left all discussions open ended, thereby allowing participants to lead the discussions and ended them promptly when they stated or indicted that they were done speaking. In the following sections, we present some lived experiences of this subset of purposefully identified participants and what they chose to narrate in response to our research interests.

\section{War in Northern Uganda}

The war began in northern Uganda in 1986, shortly after the present-day President of Uganda, Yoweri Museveni and the National Resistance Army (NRA) assumed control of the state in a coup-d'état. ${ }^{14}$ Resistance to NRA acts of terror against the predominantly Acholi inhabitants of the north came in the form of demobilized soldiers retreating and regrouping in the north, first coalescing around the leadership of Alice Lakwena, a spirit medium who hailed form the north and formed the Holy Spirit Mobile Forces (HSMF) which fought against the NRA.

In the late 1980s, Joseph Kony emerged as a spiritual leader in the north. Kony attracted different groups of rebels, including remnants of the HSMF, and followers to amass a significant army devoted to following the spiritual laws communicated through Kony and eventually forming the LRA. Following a series of military operations by the NRA - later renamed the Ugandan People's Defence Forces against the LRA, the government entered peace talks with the rebels in 1993. When the talks failed, the LRA relocated to Sudan. The LRA received military support and aid from the Sudanese Government and, in return, assisted the Sudanese Armed Forces in fighting the civil war in that country. The LRA built expansive bases in Sudan until 2003, when a Ugandan military-led offensive, Operation Iron Fist, led them to return to Uganda to fight the war there once more. The war ended in Uganda with a ceasefire in 2006 but remains ongoing in the Central African Republic, Democratic Republic of Congo and Sudan where Kony relocated with the LRA following a failed attempt at peace talks in 2008.

\section{Sexual Governance in the LRA}

Studies of the LRA in Sudan suggest that the group was organized around a military-familial unit, in which each commander acted as 'father' to new recruits, and the most senior wife acted as 'mother'. ${ }^{15}$ Abducted children were socialized through physical labour, beatings and public displays of violence, such as the beating, murder or mutilation of other recruits or of civilians. ${ }^{16}$ Such tactics were to harden the abducted child and replace their longing for home with loyalty to the movement. As one participant argued, 'We abducted young children, so they can grow into the system and adjust to the system. Just as a child starts in the nursery, they grow into primary and secondary school and university. That is why we abducted children. ${ }^{17}$

Within the LRA, sexual relations were strictly regulated according to the spiritual dictates of Alice Lakwena as communicated through Kony. Participants emphasized both the normality of rules dictating behaviour but also the gross ramifications of failing to obey the rules that governed sexual and gender relations, which included a variety of ways men and women were to interact on a daily basis to minimize the possibility of sexual transgressions. Sex was only permitted between men and women within a

\footnotetext{
${ }^{14}$ See also Akello; Barrett; and Denov, all in this volume.

${ }^{15}$ Baines 2014.

${ }^{16}$ Oloya 2013.

${ }^{17}$ Interview with 'Tony', former mid-level ranking LRA soldier who spent 17 years in the rebel group, Pader Town Council, 25 June 2015.
} 
'marriage' sanctioned by senior commanders, at a time of their determination, and between two persons they selected for it. Rape was forbidden, as were extramarital affairs. ${ }^{18}$ Nevertheless, participants acknowledged that soldiers raped newly abducted girls and women without the knowledge of commanders. Often male commanders themselves covertly raped newly abducted girls and women before their 'assignment as a wife' and would release them immediately being fully aware of the implications if they were caught. It is within this context of rules of marriage and sexual relations, and the ways these rules were broken, that participants discussed the ways they themselves or others experienced different forms of sexual violence against men and boys. We draw attention to the fact that all persons were subject to violent governance within the LRA. Therefore, most intimate and sexual relations were forged in a setting of coercion - albeit assuredly negotiated in a variety of ways which were in themselves deeply gendered. One participant explained, 'In the LRA, you can't just wake up and leave ... . every decision you make, you factor in how it will affect you and your life, every decision affects your life as it is confined within the LRA.' 19

Mindfulness of the coercive settings within the LRA allows observers to approach the experiences of men and boys within the group with the same urgency as those of women and girls. We also encourage readers to take note of the deep involvement of Kony himself within the elaborate regulation of sexual relationships within the LRA. Kony's involvement indicates the centrality of sexual regulation to the political and spiritual imperatives of the LRA and the extraordinary conditions for unsanctioned forms of sexual relations and violations. This helps us to further appreciate the silences and erasures around sexual violence against boys and men in the armed group.

The next several sections of this chapter consider various coercive relationships, specifically forced marriage, relationships in which senior women exploited boys and relationships in which senior men exploited boys.

\section{$4 \quad$ Forced marriage}

One of the more commonly documented and analysed forms of sexual violence in armed groups, including the LRA, is the practice of forced marriage. Research on forced marriage is usually conducted from the perspective of women who were often abducted as girls. Cognizant of the setting of coercion described above in which all relationships were forged, we draw attention to men's experiences of forced marriage to offer a more gender inclusive understanding of sexual violence amongst boys within the LRA. We build on our previous argument that a relational approach reveals the entanglements of power, and 'the wider web of social entanglements through which power circulates and is contested, disrupting the problematic framework of men-as-perpetrators (and thus all-powerful and in need of restraint) and women-as-victims (and thus without agency and in need of rescue). ${ }^{20}$ In settings of coercion, a relational approach reveals the various ways relationships impinge or place demands upon each other. As such it 'lets go of the gender binary', to understand how vulnerability is shaped in a dynamic set of relationships that are never static, or merely defined by domination and subordination. ${ }^{21}$

Men spoke of the many ways they were assigned a wife in the LRA. One participant recalled how he fell in love with a young woman instructed by his superior to nurse him back to health after an injury. He was eventually granted the right to marry her. This was identified as a common enough occurrence. Others talked of approaching their commanders when they felt they were ready for marriage and appealed to them for a wife. Only those who were considered loyal, hardworking and obedient were given the right to take a wife - once again at their commander's discretion. These rules were unevenly applied. Some 'would apply pressure' on their commander until their request was fulfilled. As Richard, a former Brigade commander explained, others 'were jolly and liked by the big men, and that is why they were given a wife, because they favoured their behaviour., ${ }^{22}$ Richard also commented, 'At times it was like home, depending on status and who you were you were free to speak your mind, and it was respected.' Another participant reported:

\footnotetext{
18 Baines 2014: 410.

${ }^{19}$ FGD with 9 former LRA, all abducted between the ages of 10-15 for 3-11 years, mid-level rank, Gulu District, 10 July 2014.

${ }^{20}$ Aijazi and Baines 2017: 468.

${ }^{21}$ Dolan 2014b: 498.

${ }^{22}$ Interview with 'Richard', a former LRA Brigade Commander, Gulu District, 9 July 2014.
} 
If you don't want that woman, and there is another you want, if you explain it well to the commander, they will release you [from that woman]. If you want the other one and she is fit for a specific commander, then they will remind you that she is for someone for a big commander. They will tell you that next time we will abduct another group and give you another, or next time in the field you can recruit a girl you like to keep as your wife. ${ }^{23}$

The distribution of young girls to their new homes was achieved under the oversight of the high command, often Kony himself. If a girl was premenstrual, she was taken into a commander's home to act as a ting ting - a caregiver for his children and assistant to his wives. Ting ting called the commander 'father'. When she menstruated, a ting ting was either forced to become the commander's wife or given to one of his escorts or to a new commander. Richard explained that originally, wives were released by the LRA after they gave birth. But on relocation to South Sudan in 1994, the LRA began to enforce new marriage laws to prevent extra-marital sexual relations and the desertion of their male soldiers:

Eventually, with the urge of nature, people hooked up, and there was rivalry. Say there was one woman, and then four or five people were trying to encroach on her, she would pick one and the rest would feel jealous - and would lose morale to fight. Some would even want to just go back home, because they had left their women and children at home .... Those at young age [boys abducted for fighting and domestic labour] grew up, we didn't want them to go back. That is why we did marriage. ${ }^{24}$

Another important rationale for the regulation of marriage within the LRA was to promote distinctive forms of moral purity for the creation of a 'new' and superior Acholi nation. Sex outside marriage was strictly forbidden and enforced via public forms of punishment and humiliation, such as being beaten in front of an assembly, imprisonment or execution:

In Congo, an escort to Kony slept with one of Kony's wives. The sex resulted in a pregnancy. Kony asked [his wife] how she became pregnant because they had not had sex for more than six months, so where did she get? The woman admitted that she went together with the escort. The wife and escort were both shot. ${ }^{25}$

Men regulated their interactions with women, for even the slightest of suspicions could be enough to solicit accusation, interrogation and punishment. Others stated they feared spiritual ramifications of breaking the proclaimed rules, for it was believed - and many witnessed it to be true - that the spirits guided bullets to those who broke these rules. Such was the state of coercion in which sexual or familiar relations were governed.

Only a small group of commanders close to Kony, or Kony himself, determined who could marry and when they could marry. ${ }^{26}$ Even senior commanders often did not have a choice of whom they could take as a wife, or who the girl or young woman under their care was given to. Richard, the Brigade commander in this study, argues he himself was once subject to forced marriage. Richard describes an instance where he was instructed to accept a new wife he did not want. Richard illuminates the degree to which Kony regulated the sexual relations of all those under his control, even his senior commanders, as well as how Kony imposed marriages on both men and women:

There was a time a lady was allocated to me by top leadership, I didn't want it [the marriage], I refused and explained a lot that I was not in the position to handle that lady and all that . . . but what came out for me from him [Kony], was that well, if I refused, it

\footnotetext{
${ }^{23}$ Interview with 'Tony', former mid-level ranking LRA soldier who spent 17 years in the rebel group, Pader Town Council, 25 June 2015.

${ }^{24}$ Interview with 'Richard', a former LRA Brigade commander, Gulu town, 9 July 2014.

${ }^{25}$ Interview with 'Tony', former mid-level ranking LRA soldier who spent 17 years in the rebel group, Pader Town Council, 25 June 2015.

${ }^{26}$ Carlson and Mazurana 2008.
} 
would mean I was looking for a lady amongst those he already he had, that I wanted his own wives . . so I became afraid. There was no way I could refuse. ${ }^{27}$

While Kony insisted the LRA should live as one unified Acholi and publicly discouraged favouritism amongst kin relations, nepotism reportedly took place under various political machinations. This extended to who was afforded a wife, but had to be handled carefully since, as one participant observed, there were many powerful escorts who did not have wives and who might revolt against their commander if one was favoured over another. Still, lower-ranking men could wait 10 years or more to be assigned a wife if they failed to live up to the standard expected of them to receive one. Some men reported being as young as 14 when given a wife, although most were in their mid-20s and stated they were ready. A few understood themselves as victims of forced marriage:

We used to abduct girls from an area and move with them to the position [a temporary base in the bush]. I was given a woman without being asked. I was just ordered to do it without any choice of who. I see that as being forced to marry. Our commander just distributed women to his men and told you to stay with her whether you wanted to or not. I was given to a very young girl to stay with as my wife. ${ }^{28}$

Participants recalled various times they escaped death following accusations by a commander that they coveted his wife or his prospective wife and were forced to marry someone they did not wish to wed to placate the jealousies of their commanders. It is important to be mindful of the coercive settings under which forced marriage was instituted and regulated. A participant explained: 'When you are confined, you can't just do as you please. So, if you were given a woman, you had to accept, there was no choice. It was only when we returned home, we learn this was against the law set by the Government of Uganda.' ${ }^{29}$ A community social worker we spoke with recalled a dialogue he facilitated on reconciliation in which members accused one man who had been abducted by the LRA of forced marriage and rape. The accused responded by reminding community members of the settings of coercion and regulation which governed life in the LRA: 'I was abducted at a young age, I went to the bush knowing nothing about women. You accuse me of all these crimes [forced marriage, rape, killing, abduction, looting], but I learned all this in the bush - how was I to know right from wrong? 30

\section{Senior wives and sexual violence against boys and young men}

Men described coercive sexual relations between senior ranking women and newly abducted boys. They gave an example of a female commander who took a boy of 13 to the brush and raped him while pretending to teach him how to ride a bike. They also gave an example of a boy who gave in to the sexual advances of a senior woman fearing that she would generate a rumour about him if he did not. Another participant discussed that some abducted boys agreed to have sex with senior women to gain better access to food and supplies that these women controlled. Others spoke of senior women singling out a favoured escort under their care: 'Some women had young boys as an escort - they would pick one to move to the gardens to have sex with., 31

Participants emphasized how senior women held a significant degree of decision making power over the fate of boys under their command. This power sometimes led to coercive sexual relations. A participant explained, 'She is like your mother, so you accept because she is the one who provides for you. ${ }^{32}$ Another added,

In the bush, sleeping with a woman that was not given to you is one of the biggest risks you can take. The more you do it the riskier it becomes to you. So, you must understand

\footnotetext{
${ }^{27}$ Interview with 'Richard', a former LRA Brigade Commander, Gulu town, 9 July 2014.

${ }^{28}$ FGD with 4 former LRA soldiers, all abducted at unknown ages, for an unknown timeframe and whose rank was undisclosed, Pader District, 26 June 2015.

${ }^{29}$ Individual interview with 'Kalen', LRA soldier for 9 years, abducted at age 14, Pader District, 26 June 2015.

${ }^{30}$ Interview with 'Mark', community worker, Gulu District, 19 July 2015.

${ }^{31}$ FGD with 9 former LRA, all abducted between the ages of 10-15 for 3-11 years, mid-level rank, Gulu District, 10 July 2014.

${ }^{32}$ Ibid.
} 
this context to consider the risk to the young boys entering a relationship with a sugar mummy. ${ }^{33}$

And for others, the line between coercion and choice was blurred, although relations of power remained:

That is something that really used to happen. So many young boys were given to senior women and used. Even I was given to a senior woman and used. Once you are given, you didn't have to deny - there was even love. The time I was given, I was old enough and accepted. The head of the coy [a small military unit], would arrange for me to be with that lady. ${ }^{34}$

Patricia was one of the few female soldiers who rose to the rank of captain in the LRA. She was rumoured to regularly force boys into sexual intercourse but, since no one had any proof, these rumours were just considered hearsay. At one point, Patricia was caught and seriously beaten as punishment for violating the rules. In her defence, Patricia insisted, 'If old men are receiving young girls as wives, then why are senior women not given the liberty to also receive young boys? ${ }^{35}$

Some participants believed that senior women preyed on young boys because they were sexually unsatisfied:

Some commanders had numerous wives, six or more women. He could not satisfy them all sexually. Some of these commanders were not even active sexually, they were impotent, so they could not sex - this made women want to have sex with younger boys. ${ }^{36}$

Another participant added, 'Sometimes the old, tired commanders were unable to satisfy their wives, so the wives sought young, vigorous boys. ${ }^{37}$

Despite the backdrop of coercion and control, what approximated consensual affairs also happened. Men and boys risked meeting young girls in the garden or by the well, or would 'willingly' sleep with 'big women,' or 'sugar mommies.' David aptly sums this ambiguity: 'Human beings are very funny, even if there are rules and regulations and guidelines they would go ahead and break it, but if caught they were punished or even killed! ${ }^{38}$ He elaborates the dilemma faced by many young men coming of age in the LRA, and the regulation of their sexuality: 'As human beings, the way God created us, we want intimacy - but in the bush, we were controlled, we were not allowed to express our sexuality, our intimacy was suppressed. ${ }^{39}$

As we discussed at the outset of the chapter, starting from the premise that all relationships in settings of coercion are violent provides one entry point to consider boys and men's sexual victimization. The inverse is also true: consensual affairs in such settings can be understood as a refusal of such violent impositions and beg attention to "the ways in which relationships matter, how one acts in relation to others and how this conditions experience. ${ }^{40}$

\section{Male commanders and sexual violence against boys}

We also heard reports of sexual assault of boys by senior male commanders both from within the LRA and other forces. Participants described instances when newly recruited boys were raped:

\footnotetext{
${ }^{33}$ Interview with 'Peter', a former LRA soldier, Atiak, 19 June 2015.

${ }^{34}$ FGD with 2 former LRA, abducted at unknown ages, with no or unknown rank or length, Omoro District, 18 June 2015.

${ }^{35}$ Evelyn, who spent 11 years inside the LRA, recalled this story when reviewing the draft to this chapter, 11 March 2017.

${ }^{36}$ FGD with 9 former LRA, all abducted between the ages of 10-15 for 3-11 years, mid-level rank, Gulu District, 10 July 2014.

${ }^{37}$ Ibid.

${ }^{38}$ Ibid.

${ }^{39}$ Ibid.

${ }^{40}$ Aijazi and Baines 2017.
} 
In 1995, when Kony entered Sudan we were in a tight situation and we did not have food. It was at the border of Ethiopia, the LRA were confined in a barracks with 'the Arabs' [the Sudanese Armed Forces, or SAF] - some new recruits accepted to sleep with Arabs and given food to eat; those who refused to have sex were denied food. ${ }^{41}$

A participant narrated that an LRA soldier raped him shortly after his abduction. He also observed rape happening to other boys before they were given to the high command for 'distribution.' Some participants suggested that rape of newly abducted boys happened frequently but because of heterosexist ideals of manhood these incidents went underreported. One participant named Samuel also shared his experiences of sexual assault. ${ }^{42}$ As a young boy newly abducted into the LRA, Samuel's role was to look after his commander. Samuel recalled that most nights he served dinner to his commander who would then rape him. Samuel did not report the incidents out of fear. He explained:

One thing you should know it is hard for a man to open up because we are taken to be strong and courageous and we should be able to find a solution for ourselves and that is why at first, we do not want to open about such experiences. ${ }^{43}$

Other participants stated rape of boys occurred when 'there were no girls/women' to have sex with. One participant shared,

On one occasion, several girls and boys were abducted. Before handing over the new recruits to their commander, they distributed the girls amongst the rebels who did not already have a wife. The girls were raped. But some men were still left without a girl. They turned to the boys. A boy was taken and asked: 'why didn't you bring your sisters with you? Now you will turn into a woman.' He was then raped. ${ }^{44}$

It was moreover recalled that young boys were raped when they went to collect water at isolated boreholes some distance from LRA bases. A participant told us,

There used to be a lieutenant who raped an escort. He had two wives but still slept with this boy. He was caught and killed. Kony said 'God, doesn't want this kind of sex, it was very bad.' The lieutenant was shot in public, but the escort was spared and instructed never to repeat this experience. ${ }^{45}$

\section{$7 \quad$ Discussion}

In this chapter, we have attempted to tackle the following question: why are academic and policy discourses on 'child soldiers' relatively silent on the sexual violence of boys in armed groups? Speaking from the experiences of men who were abducted by the LRA as boys and came of age under their commanders, we have sought to delineate the multiple intersecting reasons for these silences and erasures.

Legal feminist frameworks have yet to sufficiently make room for boys or men in their advocacy and policy efforts to prosecute sexual and gender-based harms as war crimes. We believe these omissions arise from a singular focus on girls and women based on a very particular reading of patriarchy which fails to consider the relational nature of sexual violence. This oversight is conceptual as well as intuitive, given the long history of the erasure of the situated and gendered experiences of women in wartime. We have attempted to show this by outlining how Erin's work with women led to this current project.

\footnotetext{
${ }^{41}$ FGD with 9 former LRA, all abducted between the ages of 10-15 for 3-11 years, mid-level rank, Gulu District, 10 July 2014.

${ }^{42}$ Interview with 'Samuel', formerly abducted, LRA ex-combatant, Acholi-bur, 11 July 2014.

${ }^{43}$ Ibid.

${ }^{44}$ Interview with 'Bob', formerly abducted, LRA ex-combatant and long-term escort to Kony, Pader Town Council, 25 June 2015.

${ }^{45}$ Interview with 'Richard', a former LRA Brigade Commander, Gulu District, 9 July 2014.
} 
We also draw attention to our earlier work, where we have argued that sexual violence such as forced marriage within armed groups cannot be understood without examining the multiple relationalities on which it is contingent. ${ }^{46} \mathrm{~A}$ relational lens draws attention to the problematic framework of men only as perpetrators in settings of coercion. Therefore, we must broaden the remit of men's relationships to women within armed groups to consider how men's relations to each other and to their children also shapes their experiences of forced marriage during wartime. A relational approach, further, enables us to move beyond an understanding of power as merely produced through patriarchy, but infused with context specific constructions of age, race, ability and sexuality as they intersect and shift in webs of relations that constitute power and its circulation. For instance, a soldier's relationship with a senior commander can, and does, shape his or her relationship with the person they were forced into a union with; the birth, life or death of a child, yet again. Understanding such interweaving and shifting relations is crucial, we suggest, to develop an adequate understanding of forced marriage as sexual violence from the perspective of boys and men.

Legalistic understandings of consent and culpability also impede our ability to imagine boys and men as victims of sexual violence. Our gaze fixates on boys and men as perpetrators. Again, this obstacle is both conceptual and intuitive, given the unequal relations of power that exist between men and women. However, our data indicate that men too, particularly boys, were also embedded within uneven relations of power, as demonstrated by the sexual violence that senior women and commanders inflicted upon them. We believe that the reductionist language of victim/perpetrator does not offer any room to substantively engage with the violations inflicted on boys and men, or even girls and women. Such dyads are not only conceptually inaccurate ${ }^{47}$ but stranglehold what is known or unknown, and seen or unseen, as consent in the sociality of violent settings, ${ }^{48}$ and the possible antagonistic contestations of the subjugated ${ }^{50}$ (such as consensual affairs as the refusal of a violently governed sexuality and intimacy).

The silences and erasures on sexual violence of boys and men can also be linked to heteronormative ideals of manhood and masculinity which discourage any conversation and inhibit reporting. ${ }^{49}$ There seems to be limited cultural vocabulary and resources to articulate these experiences. As noted by other scholars, this lack is indicative of historical and ongoing colonial suppression of alternate masculinities and sexualities in the region and elsewhere. ${ }^{50}$ Our data indicate that within settings of sexual regulation in the LRA, sexual violence occurred within the interstitial gaps between forced marriage and allowable sexual relations. This made it even more difficult to bring these violations to light as these constituted multiple levels of rules breaking, further compounding secrecy and silence. The stakes within the LRA were far too high and the consequences of reporting sexual transgressions against boys and men far too extreme for both the victim and the perpetrator. Some of our participants also described how they felt compelled to sleep with senior men or women to gain access to material advantages. These "choiceless decisions ${ }^{51}$ and pragmatism further contribute to the silences of sexual violence against boys and men.

Another major obstacle to bringing the experiences of boys into our analytical purview is the impulse to impose an age-based understanding of childhood. Age is at best a 'normative truth' rooted in Western and Euro-American traditions, which does not take into consideration wider circumstances that compel a child into adulthood, such as considerations of kinship and responsibility. ${ }^{52}$ The insistence on an age-based approach to childhood also poses significant conceptual challenges because of the pressure to then categorically separate sexual violence experienced by boys from that experienced by adults. Most of our interview participants are adult men who were forcibly conscripted into the LRA at a young age (as 'children'). Many of them came of age within the LRA, enmeshed within settings of extreme sexual regulation. Should their experiences of sexual violence both as children and adults be separated and categorized or allowed to exist as a continuum of violations within our analytical purview? This complexity was frequently demonstrated during our fieldwork when adult men would refer to themselves as 'child soldiers'. ${ }^{55}$ After all, they were abducted as children by the LRA and

\footnotetext{
${ }^{46}$ Aijazi and Baines 2017.

${ }^{47}$ Drumbl 2016.

48 Hartman 1997. ${ }^{50}$

Simpson 2016.

${ }^{49}$ Dolan 2016.

${ }^{50}$ Epprecht 2008; Stoler 1989; Nyanzi 2013; Tamale 2011.

${ }^{51}$ Aretxaga 1997.

${ }^{52}$ See also Hanson and Molima in this volume; Kamara in this volume. ${ }^{55}$

See also Ramos in this volume.
} 
became adults within that group. Age and time therefore assume a rather spectral quality, one in which child soldiers can be 'made and unmade' in the liberal humanitarian imagination..$^{53}$

Our data demonstrate that sexual violence in the LRA was contextual, dependant on a range of factors and occurred over a continuum from abduction as a child to release as an adult. Therefore, in this paper we have purposefully and methodically included a wide range of experiences of sexual violence against boys and men in the LRA including that of rape, forced marriage and instances of being forced to inflict sexual harm on others. This enriches our conceptual understanding of sexual violence. Our reading of the data suggests that there is not much value in insisting on the category of the child within the LRA, a state that was dispelled as soon as one was abducted into that armed group.

At the beginning of this paper, we mentioned Erin's encounter with Fred. Fred compels us to seriously consider that in the LRA, many/most sexual relations whether as child or adult, were forced to begin with. This provides us with an important entry point to open the very remit of sexual violence and to engage more purposefully with instances when recruits were forced to inflict sexual violence on others. In being forced to rape an elderly grandmother, was Fred not only a perpetrator but also a victim? Erin had difficulties seeing Fred as anyone but a victim given his young age, whereas Omer was open to the possibility that Fred may be considered a victim and a perpetrator. Omer was not approaching Fred as a child simply because of his age while Erin was. We realized that, intuitively, we each had very different understandings of what constitutes childhood and how that intersects with culpability. We trace this difference to our own divergent life experiences and ontologies in relation to how each one of us is placed within and/or outside Western impulses to categorize and draw straight lines, such as ones that separate children from adults.

Nadje Al-Ali and Latif Tas write that 'war is like a blanket': some aspects remain hidden while others are revealed. ${ }^{54}$ Silence on the sexual abuse of boys and men was pervasive within the LRA. One participant denied that boys were ever sexually assaulted within the group: 'I have never heard of a boy being raped. ${ }^{55}$ Another added, "I have never heard of a senior wife having a sexual relationship with a boy. ${ }^{56}$ To us, these negations suggest silence rather than absence. A participant explained,

Men who raped other men or boys kept it a secret. Why should they allow the conversation to occur? Most people see sex as something that happens between a man and a woman, not between two men. To avoid stigma, they [those who were raped] also kept it to themselves. ${ }^{57}$

Another participant added, 'When it comes to gender-based violence, most people think of women first, but boys were also raped.' ${ }^{58}$ Another stated, 'I am so happy that at last men are being invited to speak. I am irritated by the NGOs who only focus on women, because some men have suffered even more than women. 59

\section{Conclusion}

In this chapter, we have sought to understand sexual violence in armed groups from the perspective of men who were abducted as boys and came of age within the LRA. We have argued for the advancement of appropriate analytical assemblages that extend beyond ageist and gendered perspectives. We are cognizant that much additional careful work is needed to substantially reframe sexual violence from the perspectives of boys and men. This requires careful listening as well as well as a rethinking of the very conceptual scaffolding and normative assumptions on which current understandings of sexual violence rely. We take our participant's invitation to heart: 'Listen to our stories and document them well. ${ }^{60}$ REFERENCED WORKS

\footnotetext{
${ }^{53}$ Moynagh 2011; Shaw 2014.

${ }^{54} \mathrm{Al}-\mathrm{Ali}$ and Tas 2017.

${ }^{55}$ Interview with 'Tom', formerly abducted LRA soldier, Palaro Sub County, 27 June 2015.

${ }^{56}$ Interview with 'Patrick', formerly abducted LRA soldier, Palaro Sub County, 27 June 2015.

${ }^{57}$ Interview with 'Tony', former mid-level ranking LRA soldier who spent 17 years in the rebel group, Pader Town Council, 25 June 2015.

${ }^{58}$ FGD with 2 former LRA soldiers, Palaro Sub County, 27 June 2015.

${ }^{59}$ FGD with 4 former LRA soldiers, Ngoto, 26 June 2015.

${ }^{60}$ Interview with M, a survivor sexual violence of the Ugandan People's Defence Force, Koch Goma.
} 
Aijazi, O. and Baines, E. 2017. 'Relationality, Culpability and Consent in Wartime: Men's Experiences of Forced Marriage' 11 International Journal of Transitional Justice 463

Al-Ali, N. and Tas, L. 2017. "WWar Is like a Blanket" Feminist Convergences in Kurdish and Turkish Women's Rights Activism for Peace' 13 Journal of Middle East Women's Studies 354

Aretxaga, B. 1997. Shattering Silence: Women, Nationalism, and Political Subjectivity in Northern Ireland (Princeton, NJ: Princeton University Press)

Baines, E. 2014. 'Forced Marriage as a Political Project: Sexual Rules and Relations in the Lord's Resistance Army' 51 Journal of Peace Research 405

2016. Buried in the Heart: Women, Complex Victimhood and the War in Northern Uganda (Cambridge: Cambridge University Press)

Buss, D.E. 2009. 'Rethinking "Rape as a Weapon of War"' 17 Feminist Legal Studies 145

Carlson, K. and Mazurana, D. 2008. 'Forced marriage within the LRA' (Feinstein International Centre, Tufts University) (May)

Christian, M., Safari, O., Ramazani, P., Burnham, G. and Glass, N. 2011. 'Sexual and Gender-Based Violence against Men in the Democratic Republic of Congo: Effects on Survivors, their Families and the Community' 27 Medicine, Conflict and Survival 227

Chynoweth, S. 2017. 'We Keep It in Our Hearts: Sexual Violence Against Men and Boys in the Syria Crisis' (UNHCR Report) (27 November)

Chynoweth, S.K., Freccero, J. and Touquet, H. 2017. 'Sexual Violence against Men and Boys in Conflict and Forced Displacement: Implications for the Health Sector' 2017 Reproductive Health Matters 1

Clark, J.N. 2017. 'Masculinity and Male Survivors of Wartime Sexual Violence: A Bosnian Case Study' 17 Conflict, Security and Development 287

Coulter, C. 2015. Bush Wives and Girl Soldiers: Women's Lives through War and Peace in Sierra Leone (New York: Cornell University Press)

Dolan, C. 2014a. 'Into the Mainstream: Addressing Sexual Violence against Men and Boys in Conflict' (Overseas Development Institute Briefing Paper)

2014b. 'Letting Go of the Gender Binary: Charting New Pathways for Humanitarian Interventions on Gender-Based Violence' 96 International Review of the Red Cross 485 2016. 'Inclusive Gender: Why Tackling Gender Hierarchies Cannot be at the Expense of Human Rights and the Humanitarian Imperative' 98 International Review of the Red Cross 625

Drumbl, M. 2016. 'Victims who Victimise' 4 London Review of International Law 217

Epprecht, M. 2008. Heterosexual Africa? The History of an Idea from the Age of Exploration to the Age of AIDS (Athens, OH: Ohio University Press)

Hartman, S.V. 1997. Scenes of Subjection: Terror, Slavery, and Self-making in Nineteenth-century America. (Oxford: Oxford University Press)

Lewis, D.A. 2009. 'Unrecognized Victims: Sexual Violence against Men in Conflict Settings under International Law' 27 Wisconsin International Law Journal 1

Macmillan, L. 2009. 'The Child Soldier in North-South Relations' 3 International Political Sociology 36

Mibenge, C.S. 2013. Sex and International Tribunals: The Erasure of Gender from the War Narrative (Philadelphia: University of Pennsylvania Press)

Moynagh, M. 2011. 'Human Rights, Child-Soldier Narratives, and the Problem of Form' 42 Research in African Literatures 39

2014. 'Political Futurity and the Child-Soldier Figure: A Romance of Globalization' 16 Interventions: International Journal of Postcolonial Studies 655

Nyanzi, S. 2013. 'Dismantling Reified African Culture through Localised Homosexualities in Uganda' 15 Culture, Health \& Sexuality 952

Oloya, O. 2013. Child to Soldier: Stories from Joseph Kony's Lord's Resistance Army (Toronto: University of Toronto Press)

Oosterveld, V. 2014. 'Sexual Violence Directed against Men and Boys in Armed Conflict or Mass Atrocity: Addressing a Gendered Harm in International Criminal Tribunals' 10 Journal of International Law and International Relations 107

Rosemary, G. and Shepherd, L.J. 2013. “'Stop Rape Now?" Masculinity, Responsibility, and ConflictRelated Sexual Violence' 16 Men and Masculinities 115 
Schulz, P. 2018. "The "ethical loneliness" of male sexual violence survivors in Northern Uganda: gendered reflections on silencing." International Feminist Journal of Politics (published online)

Shaw, R. 2014. 'The TRC, the NGO and the Child: Young People and Post-Conflict Futures in Sierra Leone' 22 Social Anthropology 306

Simpson, A. 2016. 'The State is a Man: Theresa Spence, Loretta Saunders and the Gender of Settler Sovereignty' 19 Theory \& Event

Sivakumaran, S. 2007. 'Sexual Violence against Men in Armed Conflict' 18 European Journal of International Law 253

Solangon, S. and Patel, P. 2012. 'Sexual Violence against Men in Countries Affected by Armed Conflict' 12 Conflict, Security \& Development 417

Stoler, A.L. 1989. 'Making Empire Respectable: The Politics of Race and Sexual Morality in 20thCentury Colonial Cultures' 16 American Ethnologist 634

Tamale, S. (ed.) 2011. African Sexualities: A Reader (Cape Town: Pambazuka Press)

Touquet, H. 2018. 'Male Directed Conflict Related Sexual Violence in Sri Lanka' (International Truth and Justice Project Report)

Touquet, H. and Gorris, E. 2016. 'Out of the Shadows? The Inclusion of Men and Boys in Conceptualizations of Wartime Sexual Violence' 24 Reproductive Health Matters 36

Vojdik, V.K. 2014. 'Sexual Violence against Men and Women in War: A Masculinities Approach' 14 Nevada Law Journal 923

Ward, J. 2016. 'It's Not about the Gender Binary, It's about the Gender Hierarchy: A Reply to "Letting Go of the Gender Binary"' 98 International Review of the Red Cross 275 